\title{
'n Heilige, algemene kerk
}

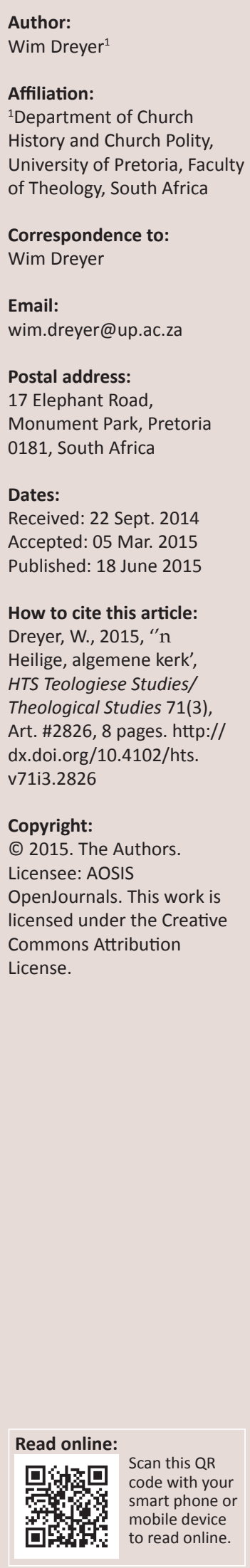

A holy, universal church. The Nicene Creed and the Apostolicum went through different processes of growth and development. In the early development of both creeds, it is noticeable that articles about 'the church' are absent. In this contribution the creeds are examined in terms of their development, the inclusion of the articles on the church, their reception during the 16th century Reformation as well as difficulties in the official Afrikaans translations. It concludes with a short exposition of the Apostolicum's article on the church (sanctam Ecclesiam catholicam).

\section{Inleiding}

As mens die ontwikkeling van die vroeë Christelike belydenisse nagaan, is dit opvallend dat 'die kerk' aanvanklik min aandag ontvang het. Dit is vanselfsprekend: 'n Mens glo in God, maar nie in 'n kerk nie. Die kerk is immers nie God of goddelik nie. Dit is verder opvallend dat verskillende belydenisse deur uiteenlopende prosesse tot stand gekom het (Cullman 1943:30).

Schaff ([1877] [1989] [1905] 1919a:63-80) het die vroegste fragmente wat dui op belydenisvorming sistematies behandel. Hy verwys onder andere na frases in die Nuwe Testament wat daarop dui dat die proses van belydenisvorming reeds vroeg in die Christelike gemeentes begin het. Vinzent (2006:84-97) bespreek G.E. Lessing (1729-1781) se standpunt, dat dele van die kerklike belydenis al voor die Nuwe Testamentiese boeke bestaan het, op ' $n$ omvattende en insiggewende wyse. Dit word nie hier herhaal nie.

Belydenisvorming in sy mees primitiewe vorm kon nie berus op skriftuurlike eksegese nie, aangesien die teks nog in wording was en die kanon nog nie vasgestel was nie. Manuskripte was ook skaars en baie gemeentes het nie toegang daartoe gehad nie. Belydenisvorming het in geloofsgemeenskappe plaasgevind en die belydenis wat ontvang is, is noukeurig van geslag tot geslag oorgelewer (paradosis). Dit is dieselfde gedagte wat ons in 1 Korintiërs 15 vind wanneer Paulus skryf:

Die belangrikste wat ek aan julle oorgelewer het en wat ek ook ontvang het, is dit: Christus het vir ons sondes gesterf,volgens die Skrifte; Hy is begrawe en op die derde dag opgewek, volgens die Skrifte. (vs. 3-5)

Die vroeë teoloë se funksie was nie om met nuwe en kreatiewe idees vorendag te kom nie of as eksegete van kanonieke boeke op te tree nie. Hulle funksie was om die Christelike geloof en belydenis, soos dit van Christus en die apostels gekom het, te verkondig, te verdedig en na 'n volgende geslag leerlinge oor te dra. Teen dié agtergrond moet ' $n$ mens ook die Belydenis van

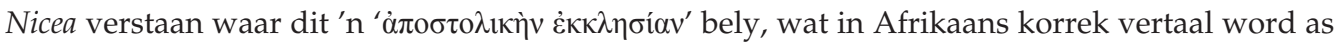
'gegrond op die leer van die apostels'.

Hierdie bydrae fokus slegs op die artikels wat oor die kerk handel in die Geloofsbelydenis van Nicea en veral die Apostoliese Geloofsbelydenis. Die Belydenis genoem na Atanasius wat deur die RoomsKatolieke, Lutherse en Calvinistiese kerke as derde 'ekumeniese' belydenis erken word bevat nie ' $n$ artikel oor die kerk nie. Die belydenis het ook eers laat, aan die einde van die vyfde eeu, in Gallië ontstaan. Daar word aandag gegee aan die ontwikkeling van die belydenis, resepsie tydens die Kerkhervorming en die vertaling daarvan in Afrikaans. Ten slotte word 'n kort verklaring van die Apostolicum se belydenis oor die kerk (sanctam Ecclesiam catholicam) gegee.

\section{Die Geloofsbelydenis van Nicea ${ }^{1}$}

Die eerste ekumeniese konsilie is deur Keiser Konstantyn in 325 n.C. in die stad Nicea byeengeroep. Hy het sowat 1800 biskoppe uitgenooi, maar waarskynlik het tussen 250 en 300 dit bygewoon. Die doel van die konsilie was om die leer oor Jesus Christus en die verhouding tussen

1.Hoewel die Geloofsbelydenis van Nicea eers met die Konsilie van Konstantinopel sy finale vorm bereik het, word in die algemeen daarna verwys as die 'Niceense belydenis' en word dit ook hier so gedoen. 
die Vader en die Seun te formuleer, in die lig van die konflik wat gedreig het om die kerk in Aleksandrië te skeur.

Die eerste deel van die Niceense belydenis is tydens die konsilie opgestel. Omdat die konsilie op die Christologie gefokus het, bevat die teks (vgl. Schaff \& Wace 1999b:3) geen verwysing na die kerk nie. Ook die Expositio Fidei van Atanasius (328 n.C.) wat hy ná die Konsilie van Nicea, waarskynlik tydens sy bevestiging as biskop (vgl. Schaff \& Wace 1999c:83-85) uitgespreek het, bevat geen verwysing na die kerk nie. Hy volg die Niceense belydenis en fokus op die verhouding tussen die Vader, Seun en Heilige Gees en die persoon en werk van Jesus Christus.

Ook 'n brief wat Eusebius van Caesarea na die Konsilie van Nicea aan sy gemeentes geskryf het (vgl. Schaff \& Wace 1999c:74-76) waarin die teks van die Niceense belydenis voorkom, het geen verwysing na die kerk nie. Die kerk het by Nicea net in die praktiese reëlings en die Canones aan die orde gekom.

$\mathrm{Na}$ afloop van die Konsilie van Nicea het die stryd teen dwaalleer (heterodoxia) voortgeduur. Verskillende variante van die Niceense belydenis was in omloop. Een van die bekendste is afkomstig van Cyrillus, biskop van Jerusalem (+386 n.C.) wat 'n uitgebreide vorm van die belydenis in sy kategetiese lesings behandel het (vgl. Gifford [1893] 1999: xlvi-xlvii in Schaff \& Wace 1999d:133-138). In die Jerusalemvariant is daar wel 'n artikel wat oor die kerk handel.

In 381 n.C. het die tweede ekumeniese konsilie in Konstantinopel (vgl. Schaff \& Wace 1999e:163) onder beskerming van keiser Theodosius vergader. By die konsilie was 150 biskoppe teenwoordig in 'n poging om die leer van Arius finaal uit te roei en die regte leer vas te stel. Cyrillus van Jerusalem was ook teenwoordig en die konsilie het waarskynlik die Jerusalem-variant van die Niceense belydenis as basisdokument gebruik. Ten opsigte van die kerk

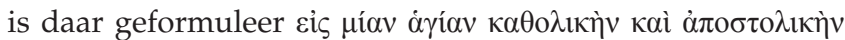
$\dot{\varepsilon} \kappa \kappa \lambda \eta \sigma i ́ \alpha v$ [Ek glo ... een, heilige, algemene en apostoliese kerk]. Dit is daarna by die Konsilie van Chalcedon (451 n.C.) bevestig en het deur die geskiedenis die kern gevorm van teologiese nadenke oor die kerk.

\section{Die Apostoliese Geloofsbelydenis ${ }^{2}$}

Die geskiedenis van die Apostolicum is meer kompleks as die van die Niceense belydenis, omdat dit nooit formeel deur een van die ekumeniese konsilies as belydenis goedgekeur is nie en dus 'n meer 'informele' groeiproses deurgegaan het. Baie Christene dink aan die Apostolicum as 'n vaste formule wat die wesenlike sake van die Christelike geloof bondig saamvat en deur die kerk amptelik goedgekeur is. Dit was ook vir baie eeue die algemene opvatting dat die belydenis uit die tyd van die apostels dateer (Kelly 1972:9), of dat die apostels dit self opgestel het.

2.Die Apostoliese Geloofsbelydenis staan ook bekend as die Twaalf Artikels of in Latyn as Symbolum Apostolorum. In hierdie artikel sal die naam Apostolicum deurlopend gebruik word. Kyk ook Nederduitse Gereformeerde Kerk (NGK) (2013:4).
Kritiese navorsing (kyk Cullman 1943:12; Pelikan 1971:117; Vinzent 2006) is eenstemmig dat die Apostolicum nie deur die twaalf apostels op skrif gestel is nie. Soos met die vasstelling van die kanon, het die leer van die kerk deur bepaalde ontwikkelingsfases gegaan. Spesifieke leerstellings het in sekere tye ontwikkel en meer prominensie geniet, hoofsaaklik in reaksie op veranderde omstandighede of bepaalde dwaalleer wat na vore gekom het.

Die vasstelling van die regula fidei was 'n lang en moeisame proses. Die 'reël van die geloof' is uiteenlopend verstaan en verwoord. Tekste van Irenaeus, Tertullianus en Hippolytus waarin frases voorkom soortgelyk aan die Apostolicum toon groot variasie in die weergawe daarvan asook die vrye gebruik en herformulering daarvan. Frases wat die meeste voorkom handel oor die Vader, Seun en Heilige Gees asook die lyding, sterwe en opstanding van Christus. Die afleiding word gemaak dat die Apostolicum aanvanklik (soos die Niceense belydenis) oor God en die verlossingswerk van Christus gehandel het (Pelikan 1971:117) en dat die artikels oor die kerk eers later bygekom het.

Pelikan (1971:150-151) is van mening dat die teks van die Apostolicum eers aan die einde van die vierde eeu sy meer bekende vorm begin aanneem het en dat die artikel oor die 'neerdaal na die hel' die laaste is wat daarin opgeneem is. Indien dit die geval is, moes die artikels oor die kerk voor die einde van die vierde eeu bygekom het, wat ooreenstem met die tyd wat die Konsilie van Konstantinopel die Niceense belydenis voltooi het en die artikels oor die kerk bygevoeg het.

Van die vroeë apologete en kerkvaders se geskrifte bevat frases soortgelyk aan dit wat ons tans in die Apostolicum het, maar die term 'symbolum apostolorum' word in 390 n.C. die eerste keer in 'n brief vermeld. Dit is deur die Sinode van Mailand (Milaan) aan Pous Siricius gerig en waarskynlik deur Ambrosius opgestel (Kelly 1972:9). In die brief (kyk Vinzent 2006:25) lees ons 'credatur symbolo apostolorum, quod ecclesia Romana intemeratum semper custodit et servat.' Daar word verwys na die doctrina wat deur Christus gegee is, deur die apostels gepreek is en nog altyd deur die kerk in Rome bewaar is. Of dit pertinent na die Apostolicum verwys is egter onseker.

In dieselfde tyd het Augustinus 'n uiteensetting van die Apostolicum opgestel (kyk Schaff \& Wace 1999a:317-333). Sy De fide et symbolo (393 n.C.) is 'n lesing wat hy voor al die biskoppe van die kerk in Noord-Afrika in Hippo-Regius gelewer het. Sy behandeling van die verskillende artikels van die Apostolicum stem grootliks ooreen met dit wat ons vandag as die Apostolicum ken. In die geval van die kerk vind ons ' $\mathrm{n}$ baie kort formulering, te wete sanctam Ecclesiam (ek glo 'n heilige kerk).

Die lesing van Augustinus het 12 jaar na die konsilie van Konstantinopel plaasgevind. 'n Mens kan aanvaar dat die konsilie se weergawe van die Niceense belydenis bekend 
en in Latyn beskikbaar moes gewees het. Tog gebruik Augustinus nie die Niceense belydenis as basis vir sy lesing oor die leer van die kerk nie, maar eerder die Apostolicum. Dit dui daarop dat die Apostolicum in die westelike deel van die kerk belangrik geag is en by voorkeur gebruik is, terwyl in die oostelike deel van die kerk die Apostolicum geen invloed uitgeoefen het nie. Hierdie tendens het ook tydens die Kerkhervorming voortgeduur.

Ons vind die term symbolum apostolorum kort daarna in 'n geskrif van Tyrannius Rufinus (345-410 n.C.), 'n monnik wat in verskillende kloosters geleef en gewerk het (ook in Jerusalem kort voor die dood van Cyrillus na wie reeds verwys is). Hy is bekend vir sy vertalings van Patristiese geskrifte en veral dié van Origines. In sy Espositio Symboli Apostolici (404 n.C.) gee hy'n uiteensetting van die Christelike geloof (Schaff [1877] [1989] [1905] 1919a:47) wat soortgelyk is aan die Apostolicum wat vandag bekend is. Opvallend genoeg bevat Rufinus se weergawe van die Apostolicum dieselfde kort formulering van die belydenis oor die kerk soos by Augustinus, te wete 'sanctam Ecclesiam'.

Naas die uiteensetting van die Apostolicum bevat Rufinus se geskrif ook die legende dat die apostels na die uitstorting van die Heilige Gees op een plek bymekaar gekom het om die inhoud van wat hulle sou verkondig, te formuleer. Volgens dié legende het elke apostel een van die twaalf artikels geformuleer en moet die ontstaan van die Apostolicum na die eerste 'teologiese konferensie' na Pinkster teruggevoer word. Volgens die kerklike tradisie het die tollenaar Matteus die artikel oor die kerk gegee.

Uit bogenoemde gegewens blyk dit dat die term symbolorum apostolorum teen die einde van die vierde eeu bekend en in algemene gebruik was. Daarna het die Apostolicum steeds kleiner tekstuele wysigings ondergaan, maar in wese dieselfde gebly. Alhoewel die Apostolicum nie soos die Niceense belydenis deur die ekumeniese konsilies goedgekeur is nie, het dit wyd invloed uitgeoefen en aanvaarding gevind.

Die feit dat die Apostolicum korter en eenvoudiger as die Niceense belydenis formuleer, het te doen met die verskil in konteks en bedoeling. Die Belydenis van Nicea is die resultaat van 'n formele proses van belydenisvorming deur die groot ekumeniese konsilies, met insette van teoloë en die bedoeling om die suiwer leer vir eens en vir altyd vas te stel, terwyl die Apostolicum aanvanklik in die gemeente van Rome ontstaan het. Dit is in kategetiese onderrig, liturgie en as deel van die doophandelinge gebruik. Teologies gesprokehet die westelike belydenisvorming die eenvoudige soteriologiese kerugma in die oog gehad, terwyl die oostelike belydenisvorming die kosmiese heilsdrama probeer verwoord het (Kelly 1972: 194-195). Dit reflekteer ook in die aanvangswoorde: 'Ons glo' teenoor 'Ek glo'. In die Niceense belydenis verwoord 'n konsilie die Christelike geloof, terwyl die Apostolicum die individu aanspreek (Nederduitse Gereformeerde Kerk [NGK] 2013:17). Daar is enkele variante van die Niceense belydenis wat ook met 'Ek glo' begin, waarskynlik ook vir liturgiese doeleindes.
Ratzinger (2005:75) verbind die Apostolicum aan Matteus 28:19 en volgende waar die opdrag gegee word dat die dissipels die mense in die Naam van die Vader, die Seun en die Heilige Gees moet doop. Hierdie Trinitariese doopformule en die praktyk om bekeerlinge uit die heidendom te katkiseer en dan te doop, het gelei tot die onwikkeling van die Apostolicum as kategismus vir die wat begerig was om gedoop te word. Tydens die doopgeleentheid is aan die dopeling die vrae gevra: Glo jy aan God die Vader, die Heerser oor alles? Glo jy aan Jesus Christus, die Seun van God? Glo jy aan die Heilige Gees? Die dopeling moes op elke vraag antwoord: Credo ... Ek glo. Die saak is meer kompleks as 'n reglynige verbintenis tussen Matteus 28 en die Apostolicum, maar Matteus 28 weerspieël tog iets van die vroeë Christelike dooppraktyke en die bestaan van 'n Trinitariese doopformule (kyk Vinzent 2006:98-193 vir 'n uitgebreide literatuurstudie oor die verband tussen die doopformule en die Apostolicum).

Cullman (1943:13-28) bespreek vyf redes vir die ontstaan van die Apostolicum, waarvan die eerste die belangrikste is:

- die kategese en doophandeling

- liturgie en prediking

- eksorsisme

- apologie in tye van vervolging

- polemiek teen dwaalleer.

Die oudste teks ${ }^{3}$ van die Apostolicum in sy huidige, bekende formaat is te vinde in die De singulis libris canonicis scarapsus van die monnik Priminius (Kelly 1972:391). Hy het aanvanklik in die klooster Quortolodora in Austrasia (Antwerpen) geleef en gewerk, daarna het hy as sendeling die suid-westelike dele van Duitsland besoek en hom in die abdy te Reichenau met die hulp van Keiser Karel Martell gevestig. Die teks dateer uit die periode tussen 710 en 724 en Priminius het dit veral gebruik in sy sendingwerk om die heidene te onderrig in die Christelike geloof. In die negende eeu is dit deur Keiser Karel die Grote in die Heilige Romeinse Ryk ingevoer (Ratzinger 2005:76) en in die tiende eeu is die Apostolicum deur Keiser Otto die Grote in Rome as doopbelydenis ingestel (Küng 1992:17).

Aangesien die Niceense belydenis die enigste is wat deur die vroeë ekumeniese sinodes goedgekeur is, aanvaar die OosOrtodokse Kerk slegs die Belydenis van Nicea as ekumeniese belydenis en geniet die Apostolicum geen erkenning nie. In die westelike kerk, beide Rooms-Katoliek en Protestant, geniet die Apostolicum groot aansien ten spyte daarvan dat dit tegnies nie 'n 'ekumeniese' belydenis is nie.

\section{'n Heilige, algemene kerk}

Soos aangetoon het dit in die tweede helfte van die vierde eeu algemene praktyk geword om die kerk deel te maak van die belydenis. Waarom sou dit so wees?

Eerstens het dit te doen gehad met die vinnige geografiese en numeriese uitbreiding van die kerk na die Edik van

3.Kyk Migne (n.d.) se weergawe van die teks. 
Milaan (313 n.C.) en die beskerming wat die keiser die kerk gebied het (kyk Dreyer 2012; Schor 2009; Stark 1996). Daar was Christelike gemeentes van Indië in die ooste tot Brittanje in die weste, van Ethiopië in die suide tot Germanië in die noorde. Die handhawing van kerklike eenheid in leer en lewe, asook die verband tussen die algemene en partikuliere kerk, het toenemend problematies geword.

Die tweede belangrike rede vind ons in Augustinus se De fide et symbolo (393 n.C.), waarna reeds verwys is. In hoofstuk 10 (kyk Schaff \& Wace 1999a:331-333) skryf Augustinus dat dwaalleraars en skeurmakers hulleself ook 'kerk' noem en organiseer volgens die gebruike van die kerk. Daarmee gee hulle voor dat hulle die ware kerk is, wat hulle nie is nie omdat hulle die suiwer leer vervals. Dit is duidelik dat die bedreiging van buite in die vorm van sektariese groepering dit onvermydelik gemaak het dat die kerk rekenskap moes gee van wie en wat die kerk van Christus is.

Derdens het die kanon reeds sy finale vorm teen 350 n.C. begin aanneem (kyk Pelikan 2005) hoewel dit nog nie formeel vasgestel is nie. In die Nuwe Testament neem die kerk 'n besonder belangrike plek in. Die Nuwe Testament bevat meer as tagtig metafore (kyk Minnear 1960) wat na die kerk verwys. Die omvattende wyse waarop die kerk aan die orde kom in die Nuwe Testament het vanselfsprekend daartoe gelei dat van die vroeë kerklike skrywers meer sistematies aan die kerk aandag gegee het. Dit word byvoorbeeld duidelik in die groei en ontwikkeling van Augustinus se ekklesiologie, veral in die wyse hoe hy toenemend van Bybelse metafore gebruik maak (kyk Vuntarde \& Van Oort 2013).

Vierdens: Aan die begin van die Christelike era was die kerk nie 'n teoretiese aangeleentheid of objek van teologiese besinning nie. Die kerk was 'n eksistensiële ruimte waar Christene met mekaar hulle geloof in Jesus Christus gedeel het. Met die groeiende temporele afstand tussen Christus en die kerk; die ontwikkeling van die amp; die vergaderings van die ampte en die primaat van die biskop van Rome; verskille oor leer en die ontstaan van sektes asook die institusionalisering van die kerk in verhouding met die keiser en owerhede, het teologiese refleksie oor 'die kerk' en die opname daarvan in die belydenis noodsaaklik geword. Aan die einde van die vierde eeu was dit belangrik om die historiese verband met Christus, die apostels en die eerste gemeentes aan te toon en die eenheid en katolisiteit van die kerk te bely.

\section{Die resepsie van die Apostolicum tydens die Reformasie}

In reformatoriese teologie het die kerk altyd 'n sentrale plek ingeneem. Dit is vanselfsprekend, aangesien dit juis om die hervorming van 'die kerk' gegaan het. Vervolgens word na enkele tekste uit die tyd verwys om die resepsie van die belydenis te illustreer, met besondere verwysing na die artikel oor die kerk.
In Luther se Klein Kategismus (1559) $)^{4}$ gebruik hy die Apostolicum as basis vir sy uiteensetting van leer. Hy vertaal die sanctam Ecclesiam catholicam met 'Ich glaube ... die heilige christliche Kirche.' Sy keuse om catholicam met 'christliche' te vertaal was daarop gemik om verwarring met die RoomsKatolieke Kerk te voorkom. Die gebruik is in die Lutherse kerk voortgesit, nie net in die Klein Kategismus nie maar ook in die vertaling van die Apostolicum self, soos die weergawe op die Evangelische Kirche in Deutschland (EKD) (1996-2015a) se webblad.

Die Confessio Augustana is op 25 Junie 1530 in Augsburg deur keiser Karl V aan die Duitse keurvorste voorgelê vir ondertekening. Die basis van die konfessie is die 'Marburger Schwabach artikels' wat Luther vroeër opgestel het (Schaff [1877] [1989] [1905] 1919a:249). Philipp Melanchthon het dit verwerk in 'n Duitse en Latynse teks, met skriftelike aanmoediging van Luther wat hom moes skuil hou na die pouslike en keiserlike ban oor hom uitgespreek is. Daarom word die Confessio Augustana hoofsaaklik aan Melanchthon toegeskryf. Opvallend genoeg is dat die Duitse en Latynse tekste nie identies aan mekaar is nie, ook waar die belydenis oor die kerk aan die orde kom.

Artikel I van die Confessio Augustana begin met 'n direkte verwysing na die Niceense belydenis: 'Ecclesiae magno consensu apud nos docent, decretum Nicaenae synodi de unitate essentiae divinae ...' (kyk Latynse teks in Evangelischlutherischen Kirche 1930:52-135). In die res van die Confessio Augustana, waar van toepassing, dien die Niceense belydenis as uitgangspunt vir die uiteensetting van die ware leer.

In Artikel VII kom die kerk aan die orde. Die inleidende sin lees: 'Item docent, quod una Sancta Ecclesia pepetuo mansura sit' [Dit word geleer, dat daar vir ewig een, heilige kerk moet bestaan]. Dit verwys duidelik na die Niceense belydenis se una sancta, maar laat tegelykertyd die catholicam et apostolicam uit. Enersyds toon dit dat Melanchthon, net soos die vadere van die vroeë kerk, redelik gemaklik met die teks van die belydenis omgegaan het. Dit is verder opvallend dat in die Duitse weergawe daarvan, dit nog verder verander na 'Es wird auch gelehrt, daß alle Zeit müsse eine heilige christliche Kirche sein und bleiben.' In die geval word die catholicam, soos in die geval met Luther se Klein Kategismus, vertaal met 'Christelik'. Die woord catholicam is konsekwent vermy.

Calvyn, in sy Geneefse Kategismus en Geloofsbelydenis (1537), gebruik (soos Luther) die Apostolicum as basis vir sy uiteensetting van die leer (kyk teks in Calvin 2012:131-223). Calvyn bly baie getrou aan die teks en formulering van die Apostolicum, ook wat die artikel oor die kerk betref. Nadat hy die Apostolicum woordeliks aangehaal het (Ie croy la saincte Eglise universelle, bl. 178), kwalifiseer hy die universele kerk met die woorde: 'Ceste societe est catholique cest a dire universelle, car il ny en point deux ou trois; mais tous les eleuz de Dieu' [Ek glo 'n heilige, algemene kerk ... Hierdie gemeenskap is katoliek,

4.Teks te vind by Evangelische Kirche in Deutschland (EKD), [1559] (1996-2015b). 
dit beteken algemeen; want daar is nie twee of drie nie, maar is almal wat deur God uitverkies is]. Calvyn gebruik dus die woorde 'katoliek' en 'algemeen' afwisselend, maar nie 'Christelik' soos Luther nie.

Hoe belangrik die leer oor die kerk vir die Calvinistiese kerke was, blyk duidelik uit die feit dat die Nederlandse Geloofsbelydenis (NGB 1561) die kerk in nege van die 39 artikels behandel. Die NGB (Artikel 28) huiwer ook nie om Cyprianus van Karthago (†258 n.C.) se kontensieuse adagium extra ecclesiam nulla salus est te verwoord en daarop te wys dat niemand hom- of haarself van die gemeente mag afsny nie ${ }^{5}$.

Die NGB is oorspronklik in Frans opgestel deur Guy de Brès (ca. 1523-1567), 'n Franssprekende uit die suidelike deel van die Nederlande. Hy was goed bekend met Calvyn en die Hugenote in Frankryk, asook die Confessio de Foy wat die Sinode van Parys in 1559 aanvaar het. Dit het ook die basis van die Confessio Belgica, of Nederlandse Geloofsbelydenis gevorm.

Die NGB (soos die Confessio Augustana) gebruik die Niceense belydenis as basis om die ware leer uiteen te sit. In Artikel 27 (kyk teks in Busch 2009:336) kom die kerk aan die orde: 'nous croyons et confessons vne seule Eglise catholique et vniuerselle, laquelle est vne saincte congregation et assemblee des vrai fideles Chrestiennes' [Ons glo en bely 'n enige, katolieke of algemene kerk, 'n heilige vergadering van almal wat waarlik in Christus glo]. In hierdie formulering van die NGB is die attribuut apostolicam afwesig.

Anders as die NGB gebruik die Heidelbergse Kategismus die Apostolicum as basis (vraag 26 tot 58). Die kategismus behandel die leer oor die kerk in Vraag 54 en beskryf die kerk as 'n daad van God (vgl. teks in Oberholzer 1986):

Die Seun van God kies uit die hele menslike geslag vir Hom 'n gemeente tot die ewige lewe uit. Die kerk word deur sy Gees en Woord, in die eenheid van die ware geloof, van die begin van die wêreld af tot die einde toe vergader, beskerm en onderhou. (bl. 79)

Die kategismus gebruik in die formulering van die vraag die Apostolicum se 'heilige, algemene kerk' maar voeg daarby 'Christelik', maar nie op dieselfde wyse as wat Luther dit gedoen het nie. In die oorspronklike Duitse teks van 1563 (kyk German Reformed Church USA 1863:186-187) lees ons 'Was glaubst du von der heiligen allgemeinen Christlichen Kirche? In die Latynse vertaling wat op gesag van Keurvors Frederik III saam met die Duitse teks uitgegee is, lees ons: 'Quid credis de sancta et catholica Christi ecclesia?' Die twee verskil dus: Die Duitse teks praat van 'n 'heilige, algemene en Christelike kerk' terwyl die Latynse teks praat van die 'heilige, algemene kerk van Christus.'

Die Duitse weergawe volg waarskynlik vir Luther met die byvoeging van 'Christelik', behalwe dat Luther die 'catholica'

5.Die amptelike Afrikaanse vertalings van die belydenisse en belydenisskrifte is te vind op die webblad van die Nederduitsch Hervormde Kerk van Afrika (NHK) (2015). met 'Christelik' vertaal het. Die probleem wat die Duitse teks van die kategismus veroorsaak, is dat 'catholica' vertaal is met 'allgemeinen', maar toe gedupliseer het met die byvoeging van 'Christelik'. Die Latynse teks het dit probeer regstel (vermoed ek) deur die genitiewe vorm te gebruik (Christi) en dus te verander na 'die kerk van Christus'.

Ons weet dat die opstellers van die kategismus, in opdrag van Frederik III doelbewus formulerings gebruik het wat aanvaarbaar sou wees vir verskillende groepe, veral die Calviniste en Lutherane in die Paltz (kyk Dreyer 2014b). Die gebrek aan kerklike eenheid en die politieke onstabiliteit wat dit geskep het was 'n belangrike rede vir die opstel van die kategismus. Die gebruik van 'n spesifieke woord soos 'Christelik' in die teks van die kategismus is 'n aanduiding hoeveel sensitiwiteit daar was by Ursinus en die ander opstellers van die kategismus vir spesifieke voorkeure en formulerings.

Uit die kort oorsig blyk dit dat die reformatoriese kategismusse telkens die Apostolicum as basis gebruik het, terwyl die meer formele belydenisskrifte (Confessio Augustana en die Nederlandse Geloofsbelydenis) die Niceense belydenis gebruik het. Dit dui daarop dat die reformatoriese vadere 'n sensitiwiteit gehad het vir die herkoms, bedoeling en aard van die belydenisse.

Die gebruik van die attribuut 'Christelik' is in die amptelike Afrikaanse vertaling van die Kategismus en die Apostolicum (waarna reeds verwys is) voortgesit. Die frase 'Ek glo aan 'n ...' is ook bygevoeg, anders as die oorspronklike Latynse teks. Schaff ([1877] [1989] [1905] 1919a:35) haal Rufinus ${ }^{6}$ aan wat verduidelik dat die 'credo in' voor die 'sanctam Ecclesiam catholicam' weggelaat is, juis omdat 'n mens nie op dieselfde wyse aan die kerk glo as in God nie. Die byvoeging in die Afrikaanse teks met die voorsetsel 'aan' ondervang die probleem taalkundig. Ek is van mening dat die attribuut 'Christelik' foutiewelik deel geword het van die Apostolicum soos dit in Afrikaanse kerke gebruik word, onder invloed van Luther en die Heidelbergse Kategismus wat dit binne 'n bepaalde konteks en om baie spesifieke redes so geformuleer het. Daar behoort volstaan te word met die vertaling 'Ek glo aan ' $n$ heilige, algemene kerk'.

\section{Sanctam Ecclesiam catholicam Inleidend}

Voordat die inhoud van die artikel bespreek word, moet 'n paar inleidende opmerkings gemaak word. Eerstens: Dit is belangrik om daarop te wys dat 'n mens die Apostolcum nie as twaalf losstaande artikels of leerstellings moet verstaan nie. Dit moet ook nie as drie leerstellings (God die Vader, Seun en Heilige Gees) met onderafdelings verstaan word nie. Die Apostolicum bely één God. Die belydenis oor die kerk is dus fundamenteel deel van die belydenis oor God. ‘Vir die

6. Non dicit "In Sanctam Ecclesiam," ne" In remissionem peccatorum," nec "In carnis resurrectionem." Si enim addidisset "in" præpositionem, una eademque vis fuisset
ren resurrectionem." Si enim addidisset "in" præpositionem, una eademque vis fuisset divina separantur ab humanis.' 
Protestantisme is dit van onopgeefbare belang dat hulle nie 'n meervoud van leerstellinge ken nie, maar slegs één' (NGK 2013:16). Ten diepste word ons geloof aan die kerk bepaal deur ons geloof in God.

Tweedens: Die uitdrukking sanctam Ecclesiam catholicam kan nie alles wat in die Skrif oor die kerk gesê word, verwoord nie. Daar is reeds verwys na die omvangryke wyse waarop die Nuwe Testament oor die kerk praat. Daar word dus nie hier gehandel oor metafore soos die kerk as die volk van God, die huisgesin van die Vader, die liggaam van Christus, die tempel van die Heilige Gees en baie ander nie. In die verband kan die werk van Minnear (1960) geraadpleeg word.

Derdens: Daar is net een kerk. Die onderskeid tussen 'n sigbare en onsigbare kerk deug nie meer nie (Busch 2003:249). Dié soort Platoniese dualisme lei daartoe dat mense die sigbare kerk as minderwaardig beskou, iets waarmee ons kan maak wat ons wil en waarvan die vorm en praktyk nie so belangrik is nie, omdat ons eendag in die hiernamaals deel van die 'eintlike' kerk sal wees. Dit lei daartoe dat die sigbare kerk dienstig word aan menslike ideale en behoeftes. Karl Barth (1956) verduidelik:

For that reason the visible and invisible church are not two churches ... The one is the form and the other the mystery of one and the self-same church. The mystery is hidden in the form, but represented and to be sought in it. (bl. 669)

Dit beteken dat die eienskappe van die kerk (eenheid, heiligheid, katolisiteit en apostolisiteit) nie net eienskappe is wat ons bely nie, maar dit is wesenlik deel van die sigbare kerk. Dit beteken dat die kerk voor die geweldige uitdaging staan om hierdie eienskappe prakties en sigbaar uit te leef.

Wat beteken dit om 'n heilige, algemene kerk te bely? In die oorspronklike teks van die Apostolicum is drie woorde ter sprake: kerk, heilig en algemeen.

\section{Ecclesia - kerk}

In Afrikaans word die woord 'kerk' as ekwivalent vir

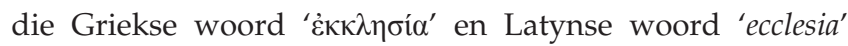
gebruik. In die Niceense belydenis en die Apostolicum word die kerk gekwalifiseer in terme van eienskappe, te wete eenheid, heiligheid, algemeenheid en apostolisiteit. Dit is hieruit duidelik dat die belydenisse nie in die eerste plek die plaaslike gemeente in gedagte het nie, maar die kerk in ekumeniese verband, die kerk soos dit deur alle tye in alle dele van die wêreld sigbaar word.

Tegelykertyd is elke plaaslike gemeenskap ook 'n gestalte van die heilige en algemene kerk. Tydens die reformasie en in die moderne kerkgeskiedenis het daar 'n verskuiwing in denke plaasgevind, deurdat die plaaslike gemeente al belangriker geword het. Daarteenoor het die ekumeniese beweging regdeur die twintigste eeu gepoog om die fokus weer terug te plaas op die eenheid en algemeenheid van die kerk. Die uitdaging waarvoor die kerk staan is om die regte balans tussen die partikuliere, plaaslike kerk en die algemene kerk te vind.

Karl Barth (1947:187) meen dat ecclesia dui op 'n versameling mense, 'n samekoms of volksvergadering wat byeengeroep word. Daarom verkies hy om (soos Luther) ecclesia eerder met 'gemeente' as 'kerk' te vertaal. Die rede vir beide se bedenkinge oor die woord 'kerk', is dat dit normaalweg dui op die kerk as instituut, terwyl beide Luther en Barth die hart van kerkwees in die gemeente vind. Teen hierdie agtergrond het Luther verkies om nie van Kirche (as die kerklike instituut) te praat nie, maar eerder van Gemeinde (as 'n lewende geloofsgemeenskap) of Volk Gottes (Barth 2009:385).

Die insig wat Luther en Barth bied, is dat die kerk konkreet in die gemeente gestalte kry, daar waar die Woord suiwer verkondig word en die sakramente volgens die instelling van Christus bedien word. Dit het in die reformatoriese tradisie bekend geword as die notae ecclesiae wat in die reformatoriese belydenisskrifte opgeneem is as die merktekens van die ware kerk. Die ware kerk se voortgang word dus nie deur die apostoliese en pouslike opeenvolging (soos in die Rooms-Katolieke Kerk) gewaarborg nie, maar deur getroue en suiwer verkondiging van die Woord. So word die kerk creatura Verbi, 'n skepping van die Woord.

In die Apostolicum is die kerk deel van die belydenis oor die Heilige Gees (Busch 2003:246). In reformatoriese teologie word die kerk altyd in verband gebring met die werking van die Woord en die Heilige Gees. Die Woord en Gees werk onlosmaaklik van mekaar. Die Woord en Gees werk interaktief om geloof te skep en die kerk te konstitueer (Kärkkäinen 2002:45). Tegelykertyd is die kerk ook weer die ruimte waar God met mense deur sy Woord en Gees op reis gaan. Die wese van die een, heilige en algemene kerk word dus nie in die kerklike strukture of in die instituut gevind nie, maar in die Woordgebeure (Barth 2009:385).

Die kerk is die moeder van die gelowiges. Luther is van oortuiging dat die sondaar, wat deur die Heilige Gees gelei word tot geloof en bekering, deur die Gees in die kerk ingelyf word. 'Wer Christus finden soll, der muss die Kirche zuerst finden' (kyk Barth 2009:387).

Vir Calvyn gaan kerkwees in die eerste plek om die

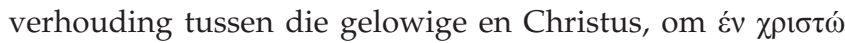
(Rm 6:11) te leef. Emil Brunner was van mening dat Calvyn se verstaan van uitverkiesing, sakramente, die kerk en heiligmaking gegrond was op sy verstaan van die eenheid met Christus, om 'in Christus' te wees (Brunner 1935:33). Calvyn het dié mistieke eenheid tussen die gelowige en Christus nie as 'n opname van die gelowige in die Goddelike bestaan beskou nie, maar eerder dat die gelowige deur die geloof en krag van die Heilige Gees met Christus een is, maar ook met alle ander gelowiges (Barth 1947:187; kyk ook Dreyer 2014a). 
Om kerk te wees beteken om in die geloof aan Christus verbonde te wees, om 'n dissipel van Christus te wees, iemand wat by Hom leer en Hom volg (Cottret, 2000:89-90; Dreyer 2014a; Neuser 2001:16). God neem die eerste inisiatief, die mens reageer en op ' $n$ resiprokale wyse ontstaan ' $n$ liefdesverhouding tussen God en mens. Die kerk bestaan binne die ruimte van God se liefde.

\section{Sanctam - heilig}

Die woord 'heilig' beteken 'afgesonder vir God' (Busch 2003:250). Die kerk behoort aan God en is geroep om aan Hom diensbaar te wees, om 'n heilige priesterdom vir hom te wees.

Die heiligheid van die kerk, net soos haar eenheid, kan nie van die sigbare kerk afgelei word nie maar kan alleen geglo word (Barth 1956:685; Bender 2005:185) en kan alleen in Christus gevind word. Omdat die kerk die liggaam van Christus is en met Christus één is, en Christus self heilig is, is die kerk ook heilig. Die kerk is menslik gesproke nie heilig nie, omdat die lidmate van die kerk sondaars is en die kerk in sy institusionele, kollektiewe gestalte al verskriklike sonde gepleeg het. Die kerk is heilig omdat Christus, deur sy bloed aan die kruis, die kerk skoon gewas het van alle skuld sodat ons sonder vlek of skande voor die troon van God kan staan.

Barth help ons om te verstaan dat die wese van die kerk ten nouste verband hou met die wese van Christus self (Webster 2000:129). Die kerk bestaan omdat Christus bestaan. Volgens Barth is die kerk die 'earthly-historical form of existence of Jesus Christ Himself' (Barth 1956:661; Bender 2005:198; Webster 2000:130). Hierdie uitsonderlike frase was bedoel as kritiek teen 'n kerkbegrip wat die kerk wou reduseer tot 'n menslike organisasie wat sy bestaansreg daarin vind om individuele belange, die volk of staat ten dienste te wees. As die kerk as die opgestane liggaam van Christus in die wêreld leef, is dit 'n kragtige getuienis dat die een, heilige kerk in gemeenskap met die heilige God leef. Die kerk mag nooit vergeet dat God heilig is, dat die kerk in Christus heilig is en daarom ook heilig moet lewe nie (Bender 2005:188).

Wie bely dat die kerk heilig is, aanvaar daarmee eweneens dat die kerk en elke lidmaat hulleself tot God moet bekeer. Die belydenis roep tot inkeer (Busch 2003:245-253). Daarom is die kerk in 'n voortdurende proses van hervorming, om kerk te wees volgens die eis van God se Woord.

\section{Catholicam - algemeen}

Die woord catholicam kan die beste vertaal word met 'algemeen', om daarmee alle verwarring te voorkom. Die algemene kerk is die kerk van alle tye, verspreid oor die hele wêreld. Dit dui op 'n algemene en omvattende identiteit, 'n kontinuïteit en universaliteit te midde van kerklike verskille of uiteenlopende gestaltes van kerkwees (Bender 2005:188). Dit hang ten nouste saam met die eenheid in Christus: Daar is net een kerk wat in wese dieselfde is te midde van diversiteit. Daarom bestaan die kerk altyd in die dialektiek van eenheid en diversiteit. Hierdie eenheid in diversiteit is moontlik waar ons met die kerk te make het, dit wil sê daar waar die kerk in ooreenstemming met die Woord die evangelie verkondig.

Eenheid en katolisiteit beteken nie eenvormigheid nie, maar dit beteken ook nie absolute vryheid nie. Dit beteken dat nie alle organisasies wat aan hulleself die naam 'kerk' toedig, deel is van die heilige, algemene kerk nie. Waar 'n 'kerk' die hart van die evangelie aantas, hou dit in wese op om kerk te wees. Daarom moet 'n kerk met fyn aandag luister na die getuienis van ander geloofsgemeenskappe, want dit beskerm jou van dwaalleer.

Wanneer gemeentes versamel in 'n Algemene Sinode of Algemene Kerkvergadering, dui die woord 'algemeen' nie op een of ander demokratiese of organisatoriese struktuur nie, maar op die feit dat die plaaslike gemeentes saamkom in die geloof, dat hulle deel is van die algemene kerk. Wanneer kerke deelneem aan ekumeniese byeenkomste saam met ander kerke, is dit in die geloof dat ons almal saam deel is van die algemene kerk. Die partikuliere en eiesoortigheid staan vir 'n oomblik in die agtergrond. Daarmee word meteens gesê dat die uitsprake van sinodes (plaaslik of internasionaal) van besondere belang is. Omdat die kerk voortdurend in 'n stryd om die waarheid gewikkel is, mag jy jou nie van die algemene kerk afskei of dit minag nie (Barth 1956:708; Bender 2005:189).

Die katolisiteit van die kerk dui ook op die openheid van die kerk in twee rigtings: Die kerk is oop na God maar ook oop na mense (Busch 2003:254-256). 'n Geslote kerk is strydig met die wese van die kerk. Die kerk is heilig, daarom afgesonder en nie van die wêreld nie, maar tegelykertyd algemeen, dus oop na die wêreld en in die wêreld. Die kerk is die volk van God wat in hierdie wêreld leef en getuig van Sy liefde. Die algemene kerk getuig dat God se koninkryk 'n werklikheid is dat almal wat bely dat Jesus Christus die Here is, burgers is van God se koninkryk.

\section{Slotwoord}

Wanneer die gemeente bely: 'Ons glo 'n heilige, algemene kerk' bely hulle dat die Heilige Gees teenwoordig is en dat Hyself deur die Woord die gemeente in aansyn roep. Die gemeente bestaan en is teenwoordig omdat God Drie-enig bestaan en teenwoordig is.

Wanneer die gemeente bely: 'Ons glo 'n heilige, algemene kerk' sê hulle van hulleself dat hulle toegewy is aan God, in sy diens staan en saam met die kerk in die wêreld getuig dat Jesus Christus die opgestane Here is, dat hulle in hulle gebede en met hulle lewe die opgestane Here sigbaar maak.

Wanneer die gemeente in geloof voor God vergader staan verdwyn sonde, strukture, gebreke en menslike foute. Dan 
verskyn die misterie van God se kerk, sy volk op reis na die nuwe Jerusalem.

\section{Erkenning \\ Mededingende belange}

Die outeur verklaar dat hy geen finansiële of persoonlike verbintenis het met enige party wat hom nadelig kon beïnvloed in die skryf van hierdie artikel nie.

\section{Literatuurverwysings}

Barth, H.-M., 2009, Die Theologie Martin Luthers. Eine kritische Würdigung Gütersloher Verlagshaus, Gütersloh.

Barth, K., 1947, Dogmatik im Grundriss im Anschluss an das apostolische Glaubensbekenntnis, W. Kohlhammer Verlag, Stuttgart.

Barth, K., 1956, Church dogmatics IV/I. The doctrine of reconcilliation, G.W. Bromiley \& T.F. Torrance (eds.), T \& T Clark, Edinburgh.

Bender, K.J., 2005, Karl Barth's christological ecclesiology, Ashgate Publishing Limited, Burlington.

Brunner, E., 1935, Vom Werk des Heiligen Geistes, Zwingli Verlag, Zürich.

Busch, E., 2003, Credo. Das Apostolische Glaubensbekenntnis, Vandenhoeck \& Ruprecht, Göttingen.

Busch, E., 2009, 'Confessio Belgica von 1561', in M. Buchsay \& E. Busch (red.) Reformierte Bekenntnisschriften, Bd. 2/1 1559-1563, bl. 335-380, Neukirchener Reformierte Bekenntnisschrif
Verlag, Neukirchen-Vluyn.

Calvin, J., [1559] 2002, Institutes of the christian religion, transl. H. Beveridge \& R.J. Dunzweiler (eds.), Christian Classics Ethereal Library, Grand Rapids, MI, viewed 26 September 2014, from http://www.ccel.org/ccel/calvin/institutes.html.

Calvin, J., 2012, Calvin studienausgabe (CS), Teilbd. 1/1, Reformatorische Anfänge (1533-1541), E. Busch, A. Heron, C. Link \& P. Opitz (eds.), Neukirchener Verlag, Neukirchen-Vluyn.

Cottret, B., 2000, Calvin. A biography, William B Eerdmans Publishing Company, Grand Rapids, MI.

Cullman, O., 1943, 'Die ersten christlichen Glaubensbekenntnisse', in H. Shaffert transl., K. Barth (ed.), Theologische Studien, Heft 15, Evangelischer Verlag, Zollikon-Zürich.

Dreyer, W.A., 2012, 'The amazing growth of the early church', HTS Teologiese Studies/ Theological Studies 68(1), Art. \#1268, 7 pages. http://dx.doi.org/10.4102/hts. v68i1.1268

Dreyer, W.A., 2014a, 'Conversio Ad Docelitam: Calvyn oor bekering en Christenwees', HTS Teologiese Studies/Theological Studies 70(3), Art. \#2094, 5 pages. http:// dx.doi.org/10.4102/

Dreyer, W.A., 2014b, 'The Heidelberg Catechism: A 16th century quest for unity', HTS Teologiese Studies/Theological Studies 70(1), Art. \#2092, 5 pages. http://dx.doi. org/10.4102/hts.v70i1.2092

Evangelische Kirche in Deutschland (EKD), 1996-2015a, Das apostolische Glaubensbekenntnis, besigtig 27 September 2014, by http://www.ekd.de/ glauben/bekenntnisse/apostolisches glaubensbekenntnis.htm

Evangelische Kirche in Deutschland (EKD), [1559] 1996-2015b, Der Kleine Katechismus: Das erste Hauptstück besigtig 01 Oktober 2014, by http://www.ekd. de/glauben/bekenntnisse/kleiner_katechismus_1.html

Evangelisch-lutherischen Kirche, 1930, Confessio Augustana. Das Augsburgische Bekenntnis (1530), Vandenhoeck \& Ruprecht, Göttingen.

German Reformed Church USA, 1863, The Heidelberg Catechism in German Latin and English: With an historical introduction, Charles Scribner, New York, NY.
Gifford, E.H., [1893] 1999, 'Introduction', in P. Schaff \& H. Wace (eds.), Nicene and Post-Nicene Fathers, vol. 7, First Series, The Seven Ecumenical Councils, pp. 1-103, Post-Nicene Fathers, vol. 7, First Series,
Hendrickson Publishers, Peabody, MA.

Kärkkäinen, V.-M., 2002, An introduction to ecclesiology. Ecumenical, historical and global perspectives, InterVarsity Press, Downers Grove, IL.

Kelly, J.N.D., 1972, Altchristliche Glaubensbekenntnisse. Geschichte und Theologie, 3. Aufl., K. Dockhorn \& A.M. Ritter transl., Vandenhoeck \& Ruprecht, Göttingen.

Küng, H., 1992, Credo. Das Apostolische Glaubensbekenntnis - Zeitgenossen erklärt, Schott, Mainz.

Migne,J.P., n.d.,'Patrologia Latina', besigtigbyhttp://www.documentacatholicaomnia. eu/1815-1875,_Migne,_Patrologia_Latina_01._Rerum_Conspectus_Pro eu/1815-1875,_Migne,_Patrologia_Latina_01._Rerum_Conspectus_ProTomis_Ordinatus
Volumen\%20089

Minnear, P.S., 1960, Images of the church in the New Testament, Westminister John KnoxPress, Louisville, KY. (The New Testament Library 2004 edn.).

Nederduitsch Hervormde Kerk van Afrika (NHK), 2015, 'Belydenisse en belydenisskrifte', besigtig by http://www.ngkerkas.co.za/wp-content/uploads/2013/04/Apostolicum. pdf

Nederduitse Gereformeerde Kerk (NGK), 2013, Die Apostoliese Geloofsbelydenis. 'n Eietydse Uitleg, Handelinge van die Algemene Sinode van die NGK 6-10 Oktober 2013, besigtig 20 September 2014, by http://www.ngkerkas.co.za/wp-content/ uploads/2013/04/Apostolicum.pdf

Neuser, W.H., 2001, 'The first outline of Calvin's theology - The preface to the New Testament in the Olivétan Bible of 1535', Koers-Bulletin for Christian Scholarship/ Bulletin vir Christelike Wetenskap 66(1/2), 1-22. http://dx.doi.org/10.4102/koers. v66i1/2.385

Oberholzer, J.P., 1986, Die Heidelbergse Kategismus, Kital, Pretoria.

Pelikan, J., 1971, The Christian Tradition, vol. 1, A history of the development of doctrine, The University of Chicago Press, Chicago, IL/London.

Pelikan, J., 2005, Whose Bible is it?, Penguin, New York, NY.

Ratzinger, J., 2005, Einführung in das Christentum. Vorlesungen über das Apostolische Glaubensbekenntnis, Kösel-Verlag, München.

Schaff, P., [1877] [1989] [1905] 1919a, The Creeds of Christendom with a history and critical notes, vol. 1 \& 2, 1889 uitgawe soos herdruk in 1905 en 1919, Harper \& Row, New York, NY.

Schaff, P., [1877] [1989] [1905] 1919b, The Creeds of Christendom with a history and critical Notes, vol 2., Harper \& Row, New York, NY.

Schaff, P. \& Wace, H., 1999a, Nicene and Post-Nicene Fathers, Series I, vol.3, The Seven Ecumenical Councils, Hendrickson Publishers, Peabody, MA.

Schaff, P. \& Wace, H., 1999b, Nicene and Post-Nicene Fathers, Series I, vol. 14, The Seven Ecumenical Councils, Hendrickson Publishers, Peabody, MA.

Schaff, P. \& Wace, H., 1999c, Nicene and Post-Nicene Fathers, Series II, vol. 4 The Seven Ecumenical Councils, Hendrickson Publishers, Peabody, MA.

Schaff, P. \& Wace, H., 1999d, Nicene and Post-Nicene Fathers, Series II, vol. 7 , The Seven Ecumenical Councils, Hendrickson Publishers, Peabody, MA

Schaff, P. \& Wace, H., 1999e, Nicene and Post-Nicene Fathers, Series II, vol. 14, The Seven Ecumenical Councils, Hendrickson Publishers, Peabody, MA.

Schor, A.M., 2009, 'Conversion by the Numbers: Benefits and pitfalls of quantitative modelling in the study of early Christian growth', Journal of Religious History 33(4), 472-498. http://dx.doi.org/10.1111/j.1467-9809.2009.00826.x

Stark, R., 1996, The rise of christianity: How the obscure, marginal Jesus movement became the dominant religious force in the Western world in a few centuries, Harper Collins, San Francisco, CA.

Vinzent, M., 2006, Der Ursprung des Apostolikums im Urteil der kritischen Forschung, Vandenhoeck \& Ruprecht, Göttingen.

Vuntarde, P.C.V. \& Van Oort, J., 2013, 'Augustine's ecclesiology and its development between 354 and 387 AD', HTS Teologiese Studies/Theological Studies 69(1), Art. \#1929, 5 pages. http://dx.doi.org/10.4102/hts.v69i1.1929

Webster, J., 2000, Barth, Continuum, London/New York, NY. 